\title{
Exogenous Application of Some Acids Enhanced the Antioxidant Activities in Strawberry Fruits and Induced the Resistance against Gray Mold Disease.
}

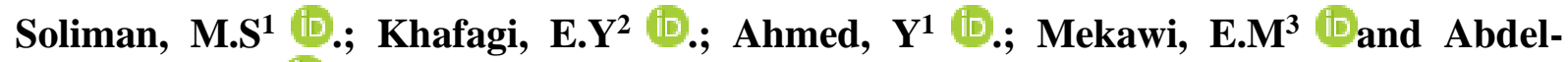 \\ Rahman, F.A ${ }^{4 *(i D)}$
}

Received: 08 January 2021 / Accepted: 11 March 2021 / Published online: 06 April 2021.

OEgyptian Phytopathological Society 2021

\begin{abstract}
Our investigation aimed to evaluate the efficacy of applying Boric, Ascorbic and Oxalic acids as foliar treatments on two strawberry cultivars, i.e., Fortuna and Sensation, during field growth, on controlling gray mold in postharvest stage. In vitro experiment revealed that all the tested acids were found to have direct fungicidal effect on $B$. cinerea growth. Oxalic acid was the most effective causing total inhibition to the fungal growth. The disease severity on strawberry fruits stored at $0 \pm 1^{\circ} \mathrm{C}$ for 21 days was significantly reduced in all treatments of acids on both tested cultivars. However, Boric acid $(40 \mathrm{mM})$ was, in general, the most effective treatment in reducing disease severity followed by Ascorbic acid $(40 \mathrm{mM})$, especially for artificially inoculated strawberry fruits, while Oxalic acid and Ascorbic acid were the least efficient in reducing disease severity at the lower concentration. The effect of different acid treatments on the activity of oxidative enzymes revealed a correlation between the reduction in disease severity and increase in enzymes activity of polyphenoloxidase (PPO) and peroxidase (POX). However, there was no consistency in the activity of catalase (CAT) in correlation with disease severity. The total phenols concentrations in fruits were significantly increased with all treatments. The free radical scavenging activity analysis in fruits showed a high correlation between the total phenols concentrations and antioxidants scavenging activities in both tested cultivars. The overall conclusion is that the acids under investigation induced a resistance against $B$. cinerea in fruits during storage and significantly suppressed gray mold severity.
\end{abstract}

Keywords: Antioxidants; Ascorbic; Boric: Oxalic acid; Botrytis cinerea; strawberry

*Correspondence: Abdel-Rahman, F.A

E-mail:fayz17102@gmail.com

Maali S. Soliman

iD https://orcid.org/0000-0002-4687-0488

Yosra Ahmed

(iD) https://orcid.org/0000-0002-1688-8871

1- Plant Quarantine Pathogens Laboratory, Mycology Research \& Disease Survey, Plant Pathology Research Institute, Agricultural Research Center, 12619, Giza, Egypt.

\section{Eman Y. Khafagi}

(iD) https://orcid.org/0000-0001-9848-504X

2- Vegetable Diseases Research Dept., Plant Pathology Research Institute, Agricultural Research Center, 12619, Giza, Egypt.

Enas M. Mekawi

(iD) https://orcid.org/0000-0001-8420-725X

3- Agricultural Biochemistry Dept., Faculty of Agriculture, Benha University, Benha, Egypt.

\section{Fayz A. Abdel-Rahman}

(iD) https://orcid.org/0000-0003-4974-3617

4 - Post-harvest Diseases Research Dept., Plant Pathology Research Institute, Agricultural Research Center, 12619, Giza, Egypt.

\section{INTRODUCTION}

Plants can sense the presence of invaders or pathogens and they also have the ability to react and defend themselves. After onsite stimulation, a downstream defense pathway is triggered involving a wide range of compounds and signals transferred systemically through plant tissues providing it with a level of resistance to a wide range of subsequent attackers; a state known as systemic acquired resistance (SAR) (Durrant and Dong, 2004; Fu and Dong, 2013). Different kinds of natural and synthetic compounds were found to mimic the effect of pathogens and provoke the plant for defense reactions. These compounds, so called "inducers or elicitors", can exogenously be applied during different plant growth stages and their effects in stimulating plant defense can prolong for some time after application conferring plants with resistance against a wide spectrum of pathogens (Walters et al., 2013). The great merit of inducing resistance in plants is the wide range of pathogens that could be targeted as the used inducers usually act by activating a broad spectrum of genes related to different defense mechanisms (Romanazzi et al., 2016; Zhou and Wang, 2018). Thus far, the inducing of resistance by chemical inducers has a preference over fungicides usage.

One of the earliest known compounds to activate systemic resistance in plants is salicylic acid (Métraux et al., 1990). It is an organic compound naturally produced inside the plants 
and plays a substantial role in SAR signaling pathways (Durrant and Dong, 2004). In addition, some synthetic compounds have been used for several years and were found to be potent inducers of plant systemic resistance. For instance, benzothiadiazole (BTH), glycerol-3phosphate (G3P) and Acibenzolar-S-methyl (ASM) proved to efficiently suppress diseases caused by various plant pathogens, e.g., Collectorichum spp., Pseudomonas syringae $p v$ 'tomato' DC3000 (Gao et al., 2014; Lawton et al., 1996; Silva et al., 2018). Moreover, previous investigations suggested that Ascorbic acid, the famous antioxidant produced by plants, can also be utilized in inducing resistance in plants. Applying Ascorbic acid on citrus tress was found to give promising results in suppressing citrus Huanglongbing (HLB) caused by Candidatus liberibacter asiaticus (Li et al., 2016).

In addition to its essentiality in plant fertilization and fortification, Boric acid was found to play a role in suppressing potato infection with black scurf disease when applied to the seed tubers during planting. However, it was suggested that this suppression in disease severity could be due to a fungicidal effect on the pathogen (Arora, 2013).

Although Oxalic acid is known to be a pathogenesis element of some plant pathogens such as Sclerotinia sclerotiorum and B. cinerea, it was reported to induce resistance in rice plants against sheath blight caused by Rhizoctonia solani when it was applied in specific minute doses (Jayaraj et al., 2010).

The induction of resistance responses in plants is accompanied with substantial changes in the metabolic processes inside plant cells. It has been proved that the different biological or environmental stresses induce reactive oxygen species in plants to very high and deleterious levels (Apel and Hirt, 2004). Investigations on the molecular and biochemical levels of the SAR in plants revealed that scavenging activities of different compounds either enzymatic or nonenzymatic significantly change during the induced resistance process in order to reduce the harmful effects of oxidative bursts. Therefore, the role of antioxidant enzymes such as peroxidases and catalases may drastically change in order to reduce and neutralize the implications of the harmful levels of oxidative bursts (Romanazzi et al., 2016).

One of the most important diseases that hamper strawberry production is gray mold caused by Botrytis cinerea Pers. Fr. which is a ubiquitous necrotrophic pathogen that has a very broad host range of plant species (Petrasch et al., 2019). Gray mold on strawberry can cause considerable losses especially during the postharvest period. In general, this pathogen favors moderate to low temperature and high humidity. The infection process is basically initiated during field growth stage, however; before harvesting; the disease sometimes remains latent and the symptoms unclear. Predominantly, strawberry fruits got stored in fridges immediately after being harvested or may directly be transferred to the marketplaces or shipped to other countries. Since the pathogen favors low temperature, it can survive during storage periods in temperatures close to zero Celsius degree (Elad et al., 2007). In optimum conditions of temperature and humidity, gray mold symptoms can be readily distinguished as brown lesions usually begin from the petioles ends of the fruits that spread very rapidly on whole fruit and petioles. Fruits turn to gray due to the complete maceration of the tissues and the growth of the pathogen distinguished by its abundance spores covering the fruit (Elad et al., 2007). Ultimately fruits desiccate due to leakage from the macerated tissues (Choquer et al., 2007). Controlling diseases caused by $B$. cinerea is a challenge since it is known with its high plasticity and genetic variability; therefore, it has the ability to always develop new strains resistant to fungicides (Hahn, 2014). Additionally, the potential hazards of using fungicides and their proved adverse effects on human, environment and microflora have led to growing need for sustainable, safe and effective means for controlling the disease. A number of chemical elicitors have been adopted in controlling diseases caused by $B$. cinerea on different plant hosts. Salicylic acid, gibberellic acid, acibenzolar and methyl jasmonate have been applied either as pre- or post-harvest treatments on different hosts to reduce the losses caused by gray mold (Terry and Joyce, 2004).

In Egypt, B. cinerea is considered to be endemic and present in all areas growing strawberries. Losses in strawberry production due to gray mold disease in Egypt can be enormous especially during post-harvest stage. Since Egypt is globally one of the top exporters of strawberry, either fresh or frozen (FAOSTAT, 2018), gray mold disease is a big threat and a great challenge for strawberry growers and exporters. However, strawberry growers are conscious to the restrictions imposed by governments on the use of chemical pesticides. Also, strawberry growing areas are subjected to surveillance programs in order to meet the global 
standards of safety and quality of fruits especially those aimed to be exported.

The purposes of our study were: 1) evaluating the effect of using Boric, Ascorbic and Oxalic acids as field treatments on the suppression of post-harvest infection of strawberry fruits with gray mold, 2) assessment of some oxidative enzymes and total phenolic compounds to elucidate the correlation between their activity and induced defense process, and 3) studying the involvement of antioxidants scavenging activity in response to using resistance inducers.

\section{MATERIALS AND METHODS}

\section{Effect of Boric, Ascorbic and Oxalic acids on the growth of $B$. cinerea in vitro:}

A virulent isolate of Botrytis cinerea (MRDS 200 ), originally isolated from rotted strawberry fruits was obtained from the collection of Mycol. Res, and Dis. Sur. Dept., Plant Pathol. Res. Inst., ARC, Giza, Egypt.

In vitro experiment was conducted to investigate the direct effect of Boric, Ascorbic and Oxalic acids on the mycelial growth of $B$. cinerea. The three acids were obtained from Sigma Chemical Co. Egypt. Each acid was tested in two concentrations, i.e., 20 and $40 \mathrm{mM}$. An Erlenmeyer flask containing $250 \mathrm{ml}$ PDA medium was prepared for each concentration of each acid. The tested acids were mixed with the melted PDA just before pouring into Petri plates. The plates were inoculated with $5 \mathrm{~mm}$ in diameter mycelia discs of 7 days old of $B$. cinerea culture (MRDS 200). Plain PDA plates inoculated with $B$. cinerea mycelia discs were used as a control. For each treatment, four plates were used as replicates. Plates were incubated at $20 \pm 1^{\circ} \mathrm{C}$ until control plates were fully grown. The diameter of the mycelial growth in plates of the different treatments was then measured and the reduction in growth was calculated using the following formula suggested by Siripornvisal $e t$ al. (2009):

$$
\% \text { Reduction }=\frac{\mathrm{A}-\mathrm{B}}{\mathrm{B}} \times 100
$$

\section{Where:}

$\mathrm{A}=$ diameter of the fungal colony of the control,

$\mathrm{B}=$ diameter of the fungal colony of the treatment.
2. Effect of spraying strawberry plants under field condition with the tested acids on postharvest infection with gray mold:

A field experiment was conducted in El Qalubya governorate, Egypt, during 2018 and 2019 growing seasons. Two strawberry cultivars were used in this experiment, i.e., Fortuna and Sensation. The experimental plot consisted of three rows each was $3 \times 0.9 \mathrm{~m}$. Strawberry plants were grown $30 \mathrm{~cm}$ apart on each row. Four plots were used as replicates for each treatment. These plots were irrigated using a drip irrigation system.

Plants were treated with Boric, Ascorbic and Oxalic acid in 20 and $40 \mathrm{mM}$ concentrations for each (Mohamed et al., 2015 and Khalil and Ashmawy 2019). Treatments were sprayed four times during the growing season. The first spray was applied 30 days after planting, the second spray was applied at the blooming stage and then spraying was repeated twice with 15 days interval. Strawberry fruits were harvested two days after last spray. Plots of each strawberry cultivar with the same aforementioned dimensions, which did not receive any treatment with the acids under investigation, were set as a control. After harvesting, fruits of each treatment were selected for absence of mechanical defects, ostensibly free from fungal diseases and for uniformity of color and shape. Fruits of each treatment were divided into two groups. The first group of fruits was surface sterilized using $70 \%$ ethanol for one min and then was artificially inoculated with $B$. cinerea. The artificial inoculation was achieved by spraying fruits with spore suspension of $B$. cinerea at about $3 \times 10^{5}$ spores $/ \mathrm{ml}$. The second group was not surface sterilized and left to natural infection. Fruits of both groups were then packed in polypropylene punnets. The fruits were stored at $0 \pm 1{ }^{\circ} \mathrm{C}$ (Ikegaya et al., 2020) and 90-95\% RH for 21 days and then disease severity was assessed. Afterwards, fruits were transferred into $20 \pm 1^{\circ} \mathrm{C}$ (Feliziani et al., 2015 ) and $95-98 \%$ RH to mimic the conditions of market shelves and then disease severity was assessed after four days. Disease severity assessment was carried out according to Romanazzi et al (2000) using the following equation:

$$
\text { Disease Severity }(\%)=\frac{\sum(\text { d f })}{(\text { X D })} \times 100
$$

where $d$ is the category of rot intensity scored on the fruit and $\mathrm{f}$ is its frequency, $\mathrm{N}$ is the total number of examined fruits (healthy and infected), and $\mathrm{D}$ is the highest category of decay intensity 
occurring on the empirical scale, using the sixdegree scale, as $0=$ healthy fruit, $1=$ decayed area of the fruit ranging from 1 to $20 \%, 2=$ decayed area of the fruit ranging from 21 to $40 \%$, $3=$ decayed area of the fruit ranging from 41 to $60 \%, 4=$ decayed area of the fruit ranging from 61 to $80 \%$, and $5=$ at least $81 \%$ of the fruit surface is infected and showing sporulation.

\section{Biochemical studies:}

The biochemical studies in this investigation were carried out on the strawberry fruits that have been incubated for 2 and 4 days at $0 \pm 1^{\circ} \mathrm{C}$ and 90-95\% RH.

Oxidative enzymes were assessed in both naturally and artificially infected strawberry fruits. The assessment was carried out in fruit tissues of each treatment, two and four days after inoculation. Three grams of fruits were blended in a mortar using liquid nitrogen. Powdered tissues were extracted in $6 \mathrm{ml}$ of $0.1 \mathrm{M}$ phosphate buffer $\left(\mathrm{PH} \mathrm{7.0)}\right.$ at $4^{\circ} \mathrm{C}$. The homogenate was centrifuged at $4000 \mathrm{rpm}$, at $4^{\circ} \mathrm{C}$ for $20 \mathrm{~min}$ (Anand et al., 2007). The crude extracts prepared from the fruits were used to determine the polyphenoloxidase, peroxidase and catalase activities assessed by photometric absorbance using spectrophotometer (Model 200UV-UNICO Instruments CO. LTD, USA as follows:

\subsection{Polyphenoloxidase activity (PPO):}

Activity of PPO was determined according to Mayer et al. (1966). The reaction mixture consisted of $1.5 \mathrm{ml}$ of $0.1 \mathrm{M}$ phosphate buffer (PH 6.5) and $200 \mu \mathrm{l}$ of the enzyme extract. $200 \mu \mathrm{l}$ of $0.01 \mathrm{M}$ catechol were added to initiate the reaction. The activity of PPO was measured by the changes in the absorbance of the reaction mixture measured at $495 \mathrm{~nm}$ using spectrophotometer. The activity was expressed as absorbance $\min ^{-1} \mathrm{~g}^{-1}$ of fruit fresh weight.

\subsection{Peroxidase activity (POX).}

Peroxidase assay (based on oxidation of pyrogallol to purpyrogallin in the presence of $\mathrm{H}_{2} \mathrm{O}_{2}$ ) was determined according to the method described by Allam and Hollis (1972). The reaction mixture contained $0.3 \mathrm{ml}$ of the crude enzyme, $0.5 \mathrm{ml}$ phosphate buffer solution ( $\mathrm{PH} \mathrm{7)}$, $0.3 \mathrm{ml}$ of $0.05 \mathrm{M}$ pyrogallol and $0.5 \mathrm{ml}$ of $1 \%$ $\mathrm{H}_{2} \mathrm{O}_{2}$. Distilled water was added to fill up the mixture up to $3 \mathrm{ml}$. Changes in absorbance at 425 $\mathrm{nm}$ by Spectrophotometer were recorded every $30 \mathrm{sec}$ for $3 \mathrm{~min}$. POX activity was expressed as the change in the absorbance of the reaction mixture min $^{-1} \mathrm{~g}^{-1}$ of fruit fresh weight according to Hammerschmidt et al. (1982).

\subsection{Catalase activity.}

Catalase enzyme was assayed according to the method described by Kato and Shimizu (1987). The reaction mixture consisted of $0.1 \mathrm{ml}$ crude extract, $0.5 \mathrm{ml} 0.2 \mathrm{M}$. phosphate buffer (PH 7.6) and $0.3 \mathrm{ml}$ of $0.5 \% \mathrm{H}_{2} \mathrm{O}_{2}$ then the mixture brought to a final volume of $3 \mathrm{ml}$ with distilled water. The breakdown of $\mathrm{H}_{2} \mathrm{O}_{2}$ was followed up by measuring the absorbance at $240 \mathrm{~nm}$ by Spectrophotometer. Moreover, the enzyme activity was calculated as the change in absorbance $\min ^{-1} \mathrm{~g}^{-1}$ of fruit fresh weight.

\subsection{Determination of Total Phenolic Contents (TPC):}

Fresh strawberry fruit samples were extracted in $95 \%$ ethanol $(1: 5 \mathrm{w} / \mathrm{v})$ at room temperature and then centrifuged at $3500 \mathrm{rpm}$ for $25 \mathrm{~min}$. Supernatants were kept for $48 \mathrm{~h}$ and filtered through Whatman No. 5 filter paper and stored in dark sealed bottles at $-20^{\circ} \mathrm{C}$ until further analysis. Folin-Ciocalteus's phenol was purchased from Merck Chemical Supplies (Darmstadt, Germany) and TPC were assessed according to the Folin-Ciocalteu method (Tulipani et al., 2008). The absorbance of the mixture was measured at $750 \mathrm{~nm}$ using spectrophotometer. Different concentrations of gallic acid were used to prepare the standard calibration curve. The TPC were expressed as milligrams of gallic acid equivalents per $100 \mathrm{~g}$ of tissues (mg GAE/100g). The absorbance values were resulted from the average of three absorbance measurements per group of samples.

\subsection{DPPH Radical Scavenging capacity:}

2,2- Diphenyl-1-picrylhydrazyl (DPPH) was obtained from Sigma-Aldrich (St. Louis, MO, USA) and the free radical scavenging capacity (RSC)was determined according to Barros et al. (2007) by the following equation:

$$
\mathrm{RSC} \%=
$$

$\frac{\text { Absorbance }_{\text {control }}-\text { Absorbance }_{\text {sample }}}{\text { Absorbance }_{\text {control }}} \times 100$

\section{Statistical analysis:}

The experimental design of both in vitro and in vivo experiments was randomized complete block with four replicates for each treatment. Analysis of the obtained results was carried out using Co-Stat 3.4 software as the usual technique of analysis of variance (Gomez and Gomez, 1984). Means were compared using least significant differences (LSD) at p 0.05 as outlined by Duncan (1955). 


\section{RESULTS}

\subsection{Effect of Boric, Ascorbic and Oxalic acids on the growth of $B$. cinerea in vitro.:}

In vitro experiment was carried out to assess the effect of the three acids under investigation on $B$. cinerea mycelial growth. Results indicated that all tested acids significantly reduced $B$. cinerea mycelial growth. However, differences among tested treatments effectiveness were noticed. Efficacy of Oxalic acid in suppressing $B$. cinerea growth was $100 \%$ at both tested concentrations. In addition, the efficacy of the higher concentration $(40 \mathrm{mM})$ of both Boric and Ascorbic acids exceeded the lower concentrations $(20 \mathrm{mM})$ in suppressing the fungal growth (Table 1).

Table (1): The antifungal effect of Boric, Ascorbic and Oxalic acids on the growth of $B$. cinerea in vitro.

\begin{tabular}{lccc}
\hline Treatment & $\begin{array}{c}\text { Conc. } \\
(\mathrm{mM})\end{array}$ & $\begin{array}{c}\text { Linear } \\
\text { growth } \\
(\mathrm{mm})\end{array}$ & $\begin{array}{c}\% \\
\text { Efficiency }\end{array}$ \\
\hline Boric acid & 20 & $43.8^{\mathrm{c}}$ & 51.3 \\
& 40 & $23.0^{\mathrm{d}}$ & 74.4 \\
\hline $\begin{array}{l}\text { Ascorbic } \\
\text { acid }\end{array}$ & 20 & $58.8^{\mathrm{b}}$ & 34.7 \\
\hline Oxalic acid & 40 & $42.3^{\mathrm{c}}$ & 53.0 \\
\hline Control & 40 & $0.0^{\mathrm{e}}$ & 100.0 \\
\hline
\end{tabular}

Within each column, same letter indicates no significant difference among treatments at P0.05.

2. Effect of spraying strawberry plants under field condition with the tested acids on the severity of post-harvest infection of fruits with gray mold during cold storage:

Treating strawberry plants during growth with the acids under investigation, affected severity of $B$. cinerea mold on fruits. For strawberry fruits stored at $0 \pm 1^{\circ} \mathrm{C}$, data revealed that the three used acids significantly decreased disease severity compared to the control (Table 2).

Boric acid gave the best protection against the disease both in artificially or naturally infected fruits followed by Ascorbic and Oxalic acid. However, increasing levels of the tested acids were more effective in suppressing the disease severity and this was clear in both successive seasons 2018 and 2019 with minor differences where the impact of the treatments during the first year was more obvious compared to the second year.

It is noteworthy that Boric acid $(40 \mathrm{mM})$ and Ascorbic acid $(40 \mathrm{mM})$ were the best treatments in reducing disease severity of artificially inoculated strawberry fruits of Fortuna cultivar. Moreover, Boric acid and Ascorbic acid at the highest concentration $(40 \mathrm{mM})$ gave complete suppression of gray mold incidence on fruits that were naturally infected compared to the untreated control in both tested strawberry cultivars. However, for the naturally infected fruits, the level of inhibition in disease severity was quite the same in all treatments for Fortuna cultivar while for Sensation there were slight differences between treatments. In regard to the cultivars, it was generally noticed that the three tested acids gave the same efficacy trend of the results for both Fortuna and Sensation. Nevertheless, slight differences were noticed in level of efficacy.

On the other hand, at $20 \pm 1^{\circ} \mathrm{C}$ incubation condition, the severity of $B$. cinerea infection was much higher for both artificially and naturally infected fruits than when kept at cold conditions; however gray mold severity was $100 \%$ in the control of artificially inoculated fruits in both tested cultivars (Table 3 ). The best treatments in reducing disease severity were Boric acid (40 $\mathrm{mM})$ and Oxalic acid $(40 \mathrm{mM})$ in artificially inoculated Fortuna cultivar. Although $20 \mathrm{mM}$ of either Oxalic acid or Ascorbic acid gave the least effect in decreasing disease severity (41.1-44\%), still their effects were significant compared to the control.

Concerning the naturally infected fruits, tested acids were quite close to each other in reducing disease severity. Boric acid, Ascorbic acid and Oxalic acid with $40 \mathrm{mM}$ concentrations were the best treatments in reducing disease severity in Fortuna cultivar. Similarly, the highest effect in suppressing disease severity in artificially inoculated Sensation fruits was 40 $\mathrm{mM}$ Boric acid while Oxalic acid showed the lowest efficacy to inhibit disease severity, however its effect was significant compared to the control. Interestingly, $40 \mathrm{mM}$ Oxalic acid was the most effective treatment in reducing disease severity of naturally infected Sensation fruits in 2019; however, $40 \mathrm{mM}$ Boric acid gave significantly similar effect.

Comparing results of Table 2 and 3, it is obvious that storage of strawberry fruits at $0 \pm 1{ }^{\circ} \mathrm{C}$ substantially lowered disease severity of gray mold compared to strawberries stored at $20 \pm 1{ }^{\circ} \mathrm{C}$ either in artificially or naturally infected fruits. 
Table (2): Effect of spraying strawberry plants under field condition (Fortuna and Sensation cultivars) with Boric, Ascorbic and Oxalic acids on severity of gray mold on stored fruits at $0 \pm 1^{\circ} \mathrm{C}$ and $90-95 \% \mathrm{RH}$ for 21 days.

\begin{tabular}{|c|c|c|c|c|c|c|c|c|c|}
\hline \multirow{3}{*}{ Treatment } & \multirow{3}{*}{$\begin{array}{l}\text { Conc. } \\
(\mathrm{mM})\end{array}$} & \multicolumn{4}{|c|}{2018} & \multicolumn{4}{|c|}{2019} \\
\hline & & \multicolumn{2}{|c|}{ Artificial infection } & \multicolumn{2}{|c|}{ Natural infection } & \multicolumn{2}{|c|}{ Artificial infection } & \multicolumn{2}{|c|}{ Natural infection } \\
\hline & & $\begin{array}{c}\% \\
\text { D.S. }\end{array}$ & $\begin{array}{c}\% \\
\text { Efficiency }\end{array}$ & $\begin{array}{c}\% \\
\text { D.S. }\end{array}$ & $\begin{array}{c}\% \\
\text { Efficiency }\end{array}$ & \% D.S. & $\begin{array}{c}\% \\
\text { Efficiency }\end{array}$ & $\%$ D.S. & $\begin{array}{c}\% \\
\text { Efficiency }\end{array}$ \\
\hline & & \multicolumn{8}{|c|}{ Fortuna cv. } \\
\hline \multirow{2}{*}{ Boric acid } & 20 & 7.9 de & 87.6 & $1.5^{b}$ & 93.2 & $10.5^{\mathrm{cd}}$ & 84.5 & $3.0^{b}$ & 88.5 \\
\hline & 40 & $3.1^{\mathrm{e}}$ & 95.1 & $0.0^{\mathrm{b}}$ & 100.0 & $4.8^{\mathrm{d}}$ & 92.9 & $1.3^{\mathrm{b}}$ & 95.0 \\
\hline \multirow{2}{*}{ Ascorbic acid } & 20 & $22.9^{c}$ & 64.0 & $3.5^{b}$ & 84.2 & $25.3^{b}$ & 62.6 & $5.2^{b}$ & 80.0 \\
\hline & 40 & $3.4^{\mathrm{e}}$ & 94.7 & $0.0^{\mathrm{b}}$ & 100.0 & $4.2^{\mathrm{d}}$ & 93.8 & $0.0^{\mathrm{b}}$ & 100.0 \\
\hline \multirow{2}{*}{ Oxalic acid } & 20 & $32.1^{\mathrm{b}}$ & 49.5 & $3.5^{b}$ & 84.2 & $30.5^{b}$ & 54.9 & $4.5^{b}$ & 82.7 \\
\hline & 40 & $14.1^{\mathrm{d}}$ & 77.8 & $0.9^{\mathrm{b}}$ & 95.9 & $17.1^{\mathrm{c}}$ & 74.7 & $1.8^{\mathrm{b}}$ & 93.1 \\
\hline \multirow[t]{2}{*}{ Control } & & $63.6^{\mathrm{a}}$ & - & $22.1^{\mathrm{a}}$ & - & $67.6^{\mathrm{a}}$ & - & $26.0^{\mathrm{a}}$ & - \\
\hline & & \multicolumn{8}{|c|}{ Sensation cv. } \\
\hline \multirow{2}{*}{ Boric acid } & 20 & $13.1^{\mathrm{d}}$ & 82.2 & $2.7^{\text {bcd }}$ & 91.8 & $16.3^{\mathrm{cd}}$ & 79.2 & $4.2^{b}$ & 88.1 \\
\hline & 40 & $6.0^{\mathrm{e}}$ & 91.8 & $0.0^{\mathrm{d}}$ & 100.0 & $8.0^{\mathrm{e}}$ & 89.8 & $0.0^{\mathrm{c}}$ & 100.0 \\
\hline \multirow{2}{*}{ Ascorbic acid } & 20 & $29.4^{b}$ & 60.0 & $4.6^{b}$ & 86.0 & $30.4^{b}$ & 61.3 & $5.9^{b}$ & 83.2 \\
\hline & 40 & $20.3^{c}$ & 72.2 & $0.0^{\mathrm{d}}$ & 100.0 & $22.6^{\mathrm{c}}$ & 71.2 & $0.0^{\mathrm{c}}$ & 100.0 \\
\hline \multirow{2}{*}{ Oxalic acid } & 20 & $20.7^{c}$ & 71.8 & $3.8^{b c}$ & 88.4 & $21.4^{\mathrm{c}}$ & 72.7 & $4.5^{b}$ & 87.2 \\
\hline & 40 & $11.2^{\mathrm{de}}$ & 84.8 & $1.4^{\mathrm{cd}}$ & 95.7 & $13.6^{\mathrm{de}}$ & 82.7 & $1.7^{\mathrm{c}}$ & 95.2 \\
\hline Control & & $73.5^{\mathrm{a}}$ & - & $32.8^{\mathrm{a}}$ & - & $78.5^{a}$ & - & $35.2^{\mathrm{a}}$ & - \\
\hline
\end{tabular}

Within each column, same letters indicate no significant difference among treatments at $(\mathrm{P}<0.05)$. D.S.= disease severity. Control was infected with B. cinerea (artificial infection) or without inoculation (natural infection).

Table (3): Effect of field spraying of strawberry plants (Fortuna and Sensation cultivars) with Boric, Ascorbic and Oxalic acids on the severity of post-harvest infection with gray mold on fruits stored at $20 \pm 1^{\circ} \mathrm{C}$ and $95-98 \%$ RH for four days

\begin{tabular}{|c|c|c|c|c|c|c|c|c|c|}
\hline \multirow{3}{*}{ Treatment } & \multirow{3}{*}{$\begin{array}{l}\text { Conc. } \\
(\mathrm{mM})\end{array}$} & \multicolumn{4}{|c|}{2018} & \multicolumn{4}{|c|}{2019} \\
\hline & & \multicolumn{2}{|c|}{ Artificial infection } & \multicolumn{2}{|c|}{ Natural infection } & \multicolumn{2}{|c|}{ Artificial infection } & \multicolumn{2}{|c|}{ Natural infection } \\
\hline & & $\begin{array}{c}\% \\
\text { D.S. }\end{array}$ & $\begin{array}{c}\% \\
\text { Efficiency }\end{array}$ & $\begin{array}{c}\% \\
\text { D.S. }\end{array}$ & $\begin{array}{c}\% \\
\text { Efficiency }\end{array}$ & $\%$ D.S. & $\begin{array}{c}\% \\
\text { Efficiency }\end{array}$ & $\%$ D.S. & $\begin{array}{c}\% \\
\text { Efficiency }\end{array}$ \\
\hline & & \multicolumn{8}{|c|}{ Fortuna cv. } \\
\hline \multirow{2}{*}{ Boric acid } & 20 & $41.6^{c}$ & 58.4 & $9.7^{\mathrm{cd}}$ & 78.0 & $43.2^{c}$ & 56.8 & $12.2^{\mathrm{cd}}$ & 74.5 \\
\hline & 40 & $31.5^{\mathrm{e}}$ & 68.5 & $4.8^{\mathrm{d}}$ & 89.1 & $34.4^{\mathrm{d}}$ & 65.6 & $5.7^{\mathrm{e}}$ & 88.1 \\
\hline \multirow{2}{*}{ Ascorbic acid } & 20 & $56.0^{b}$ & 44.0 & $15.8^{\mathrm{c}}$ & 64.2 & $58.9^{b}$ & 41.1 & $17.5^{\mathrm{bc}}$ & 63.4 \\
\hline & 40 & $33.8 \mathrm{de}$ & 66.2 & $7.3^{\mathrm{d}}$ & 83.4 & $34.9^{\mathrm{d}}$ & 65.1 & $9.8^{\mathrm{de}}$ & 79.5 \\
\hline \multirow{2}{*}{ Oxalic acid } & 20 & $58.9^{b}$ & 41.1 & $25.4^{b}$ & 42.4 & $56.2^{b}$ & 43.8 & $23.1^{b}$ & 51.7 \\
\hline & 40 & $39.6^{\mathrm{cd}}$ & 60.4 & $6.4^{\mathrm{d}}$ & 85.5 & $37.3^{\mathrm{cd}}$ & 62.7 & $7.7^{\mathrm{de}}$ & 83.9 \\
\hline \multirow[t]{2}{*}{ Control } & & $100.0^{\mathrm{a}}$ & - & $44.1^{\mathrm{a}}$ & - & $100.0^{\mathrm{a}}$ & - & $47.8^{\mathrm{a}}$ & \\
\hline & & \multicolumn{8}{|c|}{ Sensation cv. } \\
\hline \multirow{2}{*}{ Boric acid } & 20 & $40.6^{c}$ & 59.4 & $11.6^{\mathrm{cd}}$ & 77.3 & $43.2^{c}$ & 56.8 & $13.2^{\mathrm{cd}}$ & 76.4 \\
\hline & 40 & $22.6^{\mathrm{d}}$ & 77.4 & $5.7^{\mathrm{e}}$ & 88.8 & $24.2^{\mathrm{d}}$ & 75.8 & $7.4^{\mathrm{e}}$ & 86.8 \\
\hline \multirow{2}{*}{ Ascorbic acid } & 20 & $60.2^{\mathrm{b}}$ & 39.8 & $13.2^{\mathrm{c}}$ & 74.2 & $62.5^{b}$ & 37.5 & $15.1^{\mathrm{c}}$ & 73.0 \\
\hline & 40 & $45.4^{\mathrm{c}}$ & 54.6 & $7.5^{\mathrm{de}}$ & 85.3 & $48.2^{c}$ & 51.8 & $9.4^{\mathrm{de}}$ & 83.2 \\
\hline \multirow{2}{*}{ Oxalic acid } & 20 & $60.1^{\mathrm{b}}$ & 39.9 & $23.3^{b}$ & 54.4 & $63.1^{\mathrm{b}}$ & 36.9 & $22.3^{\mathrm{b}}$ & 60.2 \\
\hline & 40 & $44.7^{c}$ & 55.3 & $7.5^{\mathrm{de}}$ & 85.3 & $46.5^{c}$ & 53.5 & $5.4^{\mathrm{e}}$ & 90.4 \\
\hline Control & & $100.0^{\mathrm{a}}$ & - & $51.1^{\mathrm{a}}$ & - & $100.0^{\mathrm{a}}$ & - & $56.0^{\mathrm{a}}$ & - \\
\hline
\end{tabular}

Within each column, same letter/s indicates no significant difference among treatments at $(\mathrm{P}<0.05)$., D.S. $=$ disease severity. Control was infected with B. cinerea (artificial infection) or without inoculation (natural infection). 


\section{Biochemical studies:}

3.1. Poly phenoloxidase, peroxidase, and catalase activities:

In order to investigate the effect of different treatments on the metabolic changes in the infected Fortuna and Sensation strawberry fruits, the activity of poly phenol oxidase, peroxidase and catalase enzymes were assessed after incubation at $0 \pm 1^{\circ} \mathrm{C}$ for 2 and 4 days. Data illustrated in Figures (1, 2 and 3) generally revealed that the three acids under investigation clearly affected the activity of polyphenoloxidase, peroxidase, and catalase enzymes in tissues of infected fruits.

The increase in levels of PPO was remarkable in infected fruits of both strawberry cultivars with all acid treatments compared to the control with few exceptions (Figure 1). In addition, the increase in PPO activity was more obvious in artificially infected fruits compared to the naturally infected ones after four days of incubation. Boric acid treatment showed the highest remarkable increase in PPO activity four days post incubation in artificially infected fruits of both tested strawberry cultivars. Two days post incubation, the activity of PPO was slightly increased except in case of Ascorbic acid and Oxalic acid treatments in artificially inoculated Fortuna strawberry fruits as the activity was slightly decreased compared to control. PPO activity in the naturally infected Fortuna strawberries not treated with acids was almost similar to that of artificially inoculated ones after 2 days, while it was much higher after 4 days. Generally, PPO activity was increased in all treatments of both tested strawberry cultivars with few exceptions. Moreover, a remarkable significant increase in PPO activity was observed with Boric acid treatments 4 days post incubation in artificially inoculated fruits of both tested strawberry cultivars.

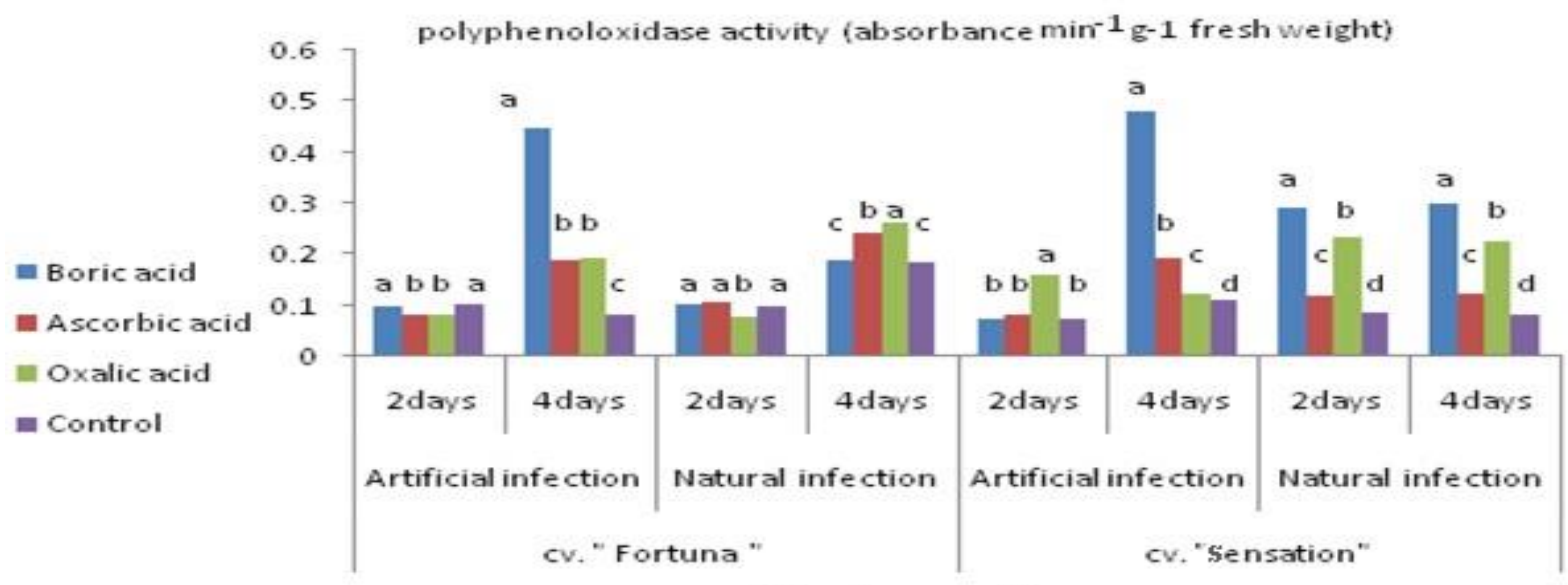

Strawberry cultivars

Figure (1): Effect of spraying strawberry plants with $40 \mathrm{mM}$ of Boric, Ascorbic and Oxalic acids on activity of poly phenoloxidase (PPO) in fruits naturally and artificially infected with $B$. cinerea during post-harvest stage after 2 and 4 days storage at $0 \pm 1^{\circ} \mathrm{C}$. Enzyme activity is expressed as absorbance $\min ^{-1}$ gram-1 fresh weight. Same letters within each incubation period ( 2 or 4 days) indicate no significant difference among treatments at $(\mathbf{P}<\mathbf{0 . 0 5})$.

Data also showed that the three acids used in this investigation significantly increased peroxidase activity in the fruits of both tested cultivars with different levels (Figure. 2). The increase in peroxidase activity was higher after 4 days of incubation than after 2 days of incubation except in Boric acid treatment of artificially inoculated Fortuna strawberries. The highest level of peroxidase activity was observed in case of Ascorbic acid treatment comparing with other treatments. This increase was remarkable in fruits of both tested strawberry cultivars after 4 days of incubation.
Concerning catalase, the activity in most treatments was decreased specifically in artificially inoculated fruits (Figure 3 ). In case of cultivar Fortuna, catalase activity was decreased significantly in Boric and Oxalic acid treatments in artificially inoculated fruits and this reduction was more obvious 4 days post incubation. However, in case of artificially inoculated fruits of Fortuna cultivar, catalase activity was obviously decreased two days post incubation in all treatments while at four days post inoculation activity was decreased in both Boric and Oxalic acid treatments compared to the control. 


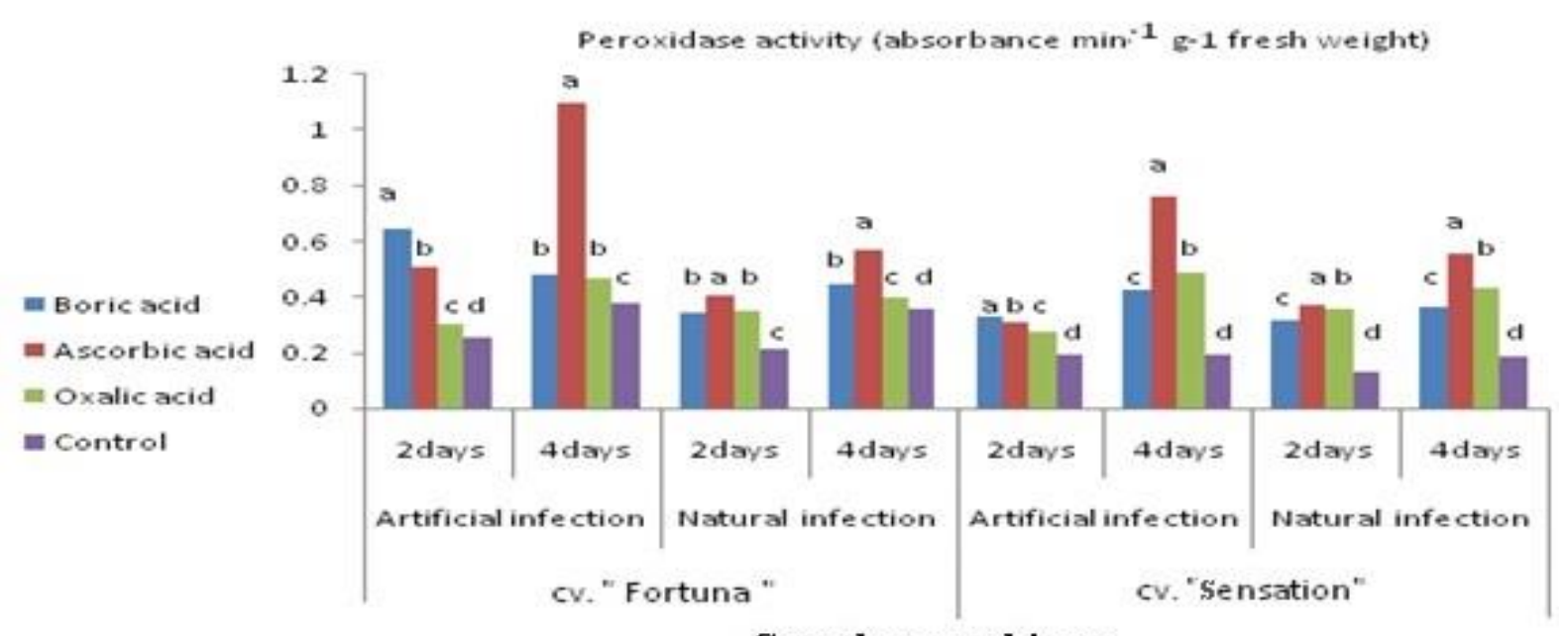

Strawberry cultivars

Figure (2): Effect of spraying strawberry plants with $40 \mathrm{mM}$ of Boric, Ascorbic and Oxalic acids on the activity of peroxidase (POX) in fruits naturally and artificially infected with $B$. cinerea during post-harvest stage after 2 and 4 days storage at $0 \pm 1^{\circ} \mathrm{C}$. Enzyme activity is expressed as absorbance min $^{-1}$ gram $^{-1}$ fresh weight. Same letters within each incubation period ( 2 or 4 days) indicate no significant difference among treatments at $(\mathbf{P}<0.05)$.

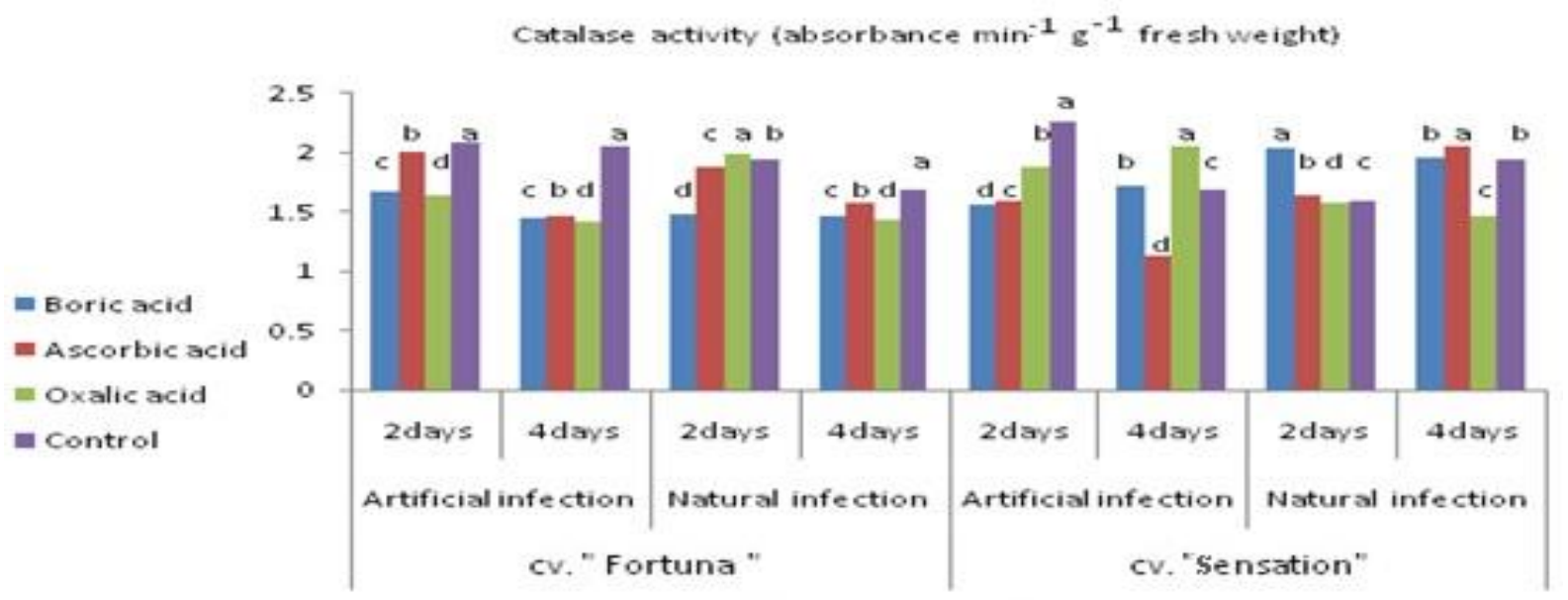

Strawberry cultivars

Figure (3): Effect of spraying strawberry plants with $40 \mathrm{mM}$ of Boric, Ascorbic and Oxalic acids on the activity of catalase (CAT) in fruits naturally and artificially infected with $B$. cinerea during post-harvest stage after 2 and 4 days storage at $0 \pm 1^{\circ} \mathrm{C}$. Enzyme activity is expressed as absorbance min $^{-1}$ gram $^{-1}$ fresh weight. Same letters within each incubation period ( 2 or 4 days) indicate no significant difference among treatments at $(P<0.05)$.

On the other hand, in naturally infected strawberry fruits of Fortuna cultivar, a significant increase in catalase activity was observed in Oxalic acid treatment at the beginning ( 2 days incubation) then it was significantly decreased later on (4 days post incubation) compared to the control. In addition, catalase activity remarkably increased in Boric acid treatment for naturally infected fruits of Sensation cultivar after 2 days of incubation compared to the control while the activity of the enzyme in Ascorbic acid treatment was significantly increased in fruits after 4 days of incubation.

\subsection{Determination of total phenols content and free radical scavenging activity:}

Results presented in Table (4) clearly show that treating plants with the three acids used in this investigation significantly enhanced total phenolic content (TPC) compared to the control treatment. It is also noticeable that artificially inoculated fruits gave higher levels of TPC in most treatments compared to naturally infected ones in both tested strawberry cultivars (Table 4). In control treatments, it is clear that the levels of total phenolic compounds in Fortuna cv. were 
higher compared to Sensation cv. either naturally or artificially infected fruits. For instance, TPC in Fortuna cv. was $866.86 \mathrm{mg}$ while it was 518.28 $\mathrm{mg}$ in Sensation cv. 4 days post incubation. In addition, the increase in TPC content was remarkable in artificially inoculated strawberry fruits of cultivar Sensation $(2055.43 \mathrm{mg}$ ) treated with high concentration of Oxalic acid (40 mM) as well as in fruits treated with Ascorbic and Boric acid treatments (2026.86 and $1706.86 \mathrm{mg}$, respectively).

Data presented in Table (5) show the free radicals scavenging activity in strawberry fruit tissues interpreted according to the DPPH radicals' elimination assay. Data clearly indicate that the different treatments by Boric, Ascorbic and Oxalic acids enhanced the antioxidant activities in fruits tissues compared to the control treatment. Data show that the scavenging activity was higher in fruits 4 days post incubation compared to 2 days post incubation. In addition, the effect of Oxalic acid in antioxidant scavenging activity in Sensation cv. was higher compared to the other used elicitors especially in case of using $40 \mathrm{mM}$ concentration, whereas in Fortuna cv. the effect of using $40 \mathrm{mM}$ of Boric acid in scavenging levels was better compared to using Oxalic or Boric acids. Furthermore, there was a high correlation between the TPC concentration and the scavenging activity.

Table (4): Effect of spraying strawberry plants under field condition (Fortuna and Sensation cultivars) with Boric, Ascorbic and Oxalic acids on the total phenolic contents (TPC) in strawberry fruits (mg/100g fresh tissues).

\begin{tabular}{|c|c|c|c|c|c|c|c|c|c|}
\hline \multirow{3}{*}{ Treatment } & \multirow{3}{*}{$\begin{array}{l}\text { Conc. } \\
(\mathrm{mM})\end{array}$} & \multicolumn{4}{|c|}{ Fortuna cv. } & \multicolumn{4}{|c|}{ Sensation cv. } \\
\hline & & \multicolumn{2}{|c|}{ Artificial infection } & \multicolumn{2}{|c|}{ Natural infection } & \multicolumn{2}{|c|}{ Artificial infection } & \multicolumn{2}{|c|}{ Natural infection } \\
\hline & & 2 days & 4 days & 2 days & 4 days & 2 days & 4 days & 2 days & 4 days \\
\hline \multirow{2}{*}{ Boric acid } & 20 & $912.5^{\mathrm{d}}$ & $969.7^{d}$ & $882.2^{\mathrm{d}}$ & $992.6^{\mathrm{d}}$ & $546.3^{e}$ & $535.4^{\mathrm{f}}$ & $917.7^{c}$ & $1489.7^{\mathrm{a}}$ \\
\hline & 40 & $1175.2^{\mathrm{a}}$ & $1377.2^{\mathrm{a}}$ & $1034.2^{b}$ & $1209.7^{\mathrm{c}}$ & $1120.8^{a}$ & $1706.9^{c}$ & $1077.1^{\mathrm{a}}$ & $1272.6^{\mathrm{b}}$ \\
\hline \multirow{2}{*}{ Ascorbic acid } & 20 & $821.4^{\mathrm{e}}$ & $844.0^{\mathrm{e}}$ & $1117.7^{\mathrm{a}}$ & $1232.6^{\mathrm{b}}$ & $824.9^{d}$ & $1089.7^{\mathrm{e}}$ & $765.2^{\mathrm{e}}$ & $924.0^{\mathrm{e}}$ \\
\hline & 40 & $1043.2^{\mathrm{b}}$ & $1146.9^{b}$ & $998.3^{c}$ & $1741.1^{\mathrm{a}}$ & $1020.5^{b}$ & $2026.9^{b}$ & $922.1^{\mathrm{c}}$ & $1158.3^{\mathrm{c}}$ \\
\hline \multirow{2}{*}{ Oxalic acid } & 20 & $811.2^{\mathrm{e}}$ & $826.9^{g}$ & $776.5^{\mathrm{e}}$ & $924.0^{\mathrm{e}}$ & $976.1^{\mathrm{c}}$ & $1192.6^{\mathrm{d}}$ & $876.1^{d}$ & $1055.4^{\mathrm{d}}$ \\
\hline & 40 & $988.7^{\mathrm{c}}$ & $1032.6^{c}$ & $883.8^{\mathrm{d}}$ & $935.4^{\mathrm{e}}$ & $1112.1^{\mathrm{a}}$ & $2055.4^{\mathrm{a}}$ & $1065.4^{b}$ & $1278.3^{b}$ \\
\hline Control & & $721.0^{f}$ & $866.9^{\mathrm{e}}$ & $623.2^{f}$ & $772.6^{f}$ & $466.6^{f}$ & $518.3^{g}$ & $402.2^{\mathrm{f}}$ & $422.4^{\mathrm{f}}$ \\
\hline
\end{tabular}

Within each column, same letter/s indicates no significant difference among treatments at $(\mathrm{P}<0.05)$. Control was infected with B. cinerea (artificial infection) or without inoculation (natural infection).

Table (5): Effect of spraying strawberry plants under field condition (Fortuna and Sensation cultivars) with Boric, Ascorbic and Oxalic acids on DPPH radical scavenging capacity (RSC \%) in strawberry fruits.

\begin{tabular}{|c|c|c|c|c|c|c|c|c|c|}
\hline \multirow{3}{*}{ Treatment } & \multirow{3}{*}{$\begin{array}{l}\text { Conc } \\
. \mathrm{mM}\end{array}$} & \multicolumn{4}{|c|}{ Fortuna cv. } & \multicolumn{4}{|c|}{ Sensation cv. } \\
\hline & & \multicolumn{2}{|c|}{ Artificial infection } & \multicolumn{2}{|c|}{ Natural infection } & \multicolumn{2}{|c|}{ Artificial infection } & \multicolumn{2}{|c|}{ Natural infection } \\
\hline & & 2 days & 4 days & 2 days & 4 days & 2 days & 4 days & 2 days & 4 days \\
\hline \multirow{2}{*}{ Boric acid } & 20 & $54.6^{\text {abcd }}$ & $54.2^{\mathrm{ab}}$ & $55.2^{\mathrm{bc}}$ & $54.3^{\mathrm{bc}}$ & $61.9^{\mathrm{a}}$ & $62.9^{\mathrm{a}}$ & $54.5^{\mathrm{bc}}$ & $43.7^{\mathrm{d}}$ \\
\hline & 40 & $50.6^{\mathrm{d}}$ & $49.3^{\mathrm{d}}$ & $53.1^{\text {bcd }}$ & $52.1^{\mathrm{c}}$ & $50.4^{\mathrm{c}}$ & $39.3^{c}$ & $51.2^{\mathrm{c}}$ & $48.2^{\text {cd }}$ \\
\hline \multirow{2}{*}{ Ascorbic acid } & 20 & $56.4^{\mathrm{abc}}$ & $56.7^{\mathrm{a}}$ & $50.4^{d}$ & $40.3^{d}$ & $56.3^{b}$ & $51.8^{b}$ & $57.5^{b}$ & $55.1^{\mathrm{b}}$ \\
\hline & 40 & $51.9^{\mathrm{cd}}$ & $50.6^{\mathrm{cd}}$ & $52.8^{\mathrm{cd}}$ & $35.3^{e}$ & $52.4^{\mathrm{bc}}$ & $32.8^{\mathrm{d}}$ & $54.4^{\mathrm{bc}}$ & $50.4^{\mathrm{bc}}$ \\
\hline \multirow{2}{*}{ Oxalic acid } & 20 & $56.5^{\mathrm{ab}}$ & $57.1^{\mathrm{a}}$ & $57.3^{\mathrm{ab}}$ & $60.2^{\mathrm{a}}$ & $53.3^{\mathrm{bc}}$ & $49.7^{b}$ & $55.3^{\mathrm{bc}}$ & $51.3^{\mathrm{bc}}$ \\
\hline & 40 & $53.0^{\mathrm{bcd}}$ & $52.9^{\mathrm{bc}}$ & $55.1^{\mathrm{bc}}$ & $51.2^{c}$ & $50.5^{c}$ & $32.3^{\mathrm{d}}$ & $51.5^{\mathrm{c}}$ & $47.9^{\mathrm{cd}}$ \\
\hline Control & & $58.4^{\mathrm{a}}$ & $56.2^{\mathrm{ab}}$ & $60.4^{a}$ & $57.3^{\mathrm{ab}}$ & $63.6^{\mathrm{a}}$ & $63.3^{\mathrm{a}}$ & $64.5^{\mathrm{a}}$ & $62.2^{\mathrm{a}}$ \\
\hline
\end{tabular}

Within each column, same letter/s indicate no significant difference among treatments at $(\mathrm{P}<0.05)$. Control was infected with B. cinerea (artificial infection) or without inoculation (natural infection).

\section{DISCUSSION}

The growing need of safe and effective alternatives for chemical fungicides have led to a great interest in the field of systemic acquired resistance in which organic and synthetic chemicals can be exploited in inducing resistance against plant pathogens and hence control or mitigate the effect of plant diseases (Durrant and Dong, 2004). In this investigation we aimed the assessment of the potential of using different acids, i.e., Boric, Ascorbic and Oxalic, in 
inducing defense in strawberry plants against gray mold caused by $B$. cinerea. The applications were carried out during field growth period while the impact was studied in the fruits during postharvest storage period.

A preliminary assessment was carried out in order to investigate the fungicidal effect of the tested acids against $B$. cinerea. An in vitro experiment revealed that all used compounds can inhibit the growth of the fungus. However, Oxalic acid was extremely toxic to $B$. cinerea for it caused complete suppression to the fungus growth. Although most of the commonly used chemical inducers act by activating resistance in plants do not directly affect the pathogens, but some inducers were also reported to have direct suppressive effect on the pathogens. Methyl jasmonate is an inducer that proved to suppress B. cinerea growth (Meir et al., 1998). In addition to its widely usage in inducing plant resistance, chitosan was also reported to have a direct antifungal property against different plant pathogens including $B$. cinerea (Mohammadi et al., 2015; Terry and Joyce, 2004).

In an investigation carried out by Qin et al. (2010) they found that using boron, in the form of potassium tetraborate, in control $B$. cinerea during postharvest was partially correlated to the inhibition of the mycelial growth of the fungus in addition to the suppression of spore germination. Furthermore, borate (the common form of boron in nature) was proved to have antifungal activity against Colletrorichum gloeosporioides, the casual pathogen of anthracnose in different host plants, by causing complete damage to the mitochondria of the fungus (Shi et al., 2012). Moreover, in vitro studies on Ascorbic acid revealed their antifungal effect against Alternaria solani and A. brassicicola (Awadalla, 2008; Botanga et al., 2012). In addition, Ascorbic acid has antimicrobial activity against a large number of bacterial species infecting plants and also a broad range of bacteria associated with human diseases (Li et al., 2016).

In this investigation, the application of the three tested acids was carried out four times during field growth period and the effect on the severity of infection with gray mold was assessed during storage period. Data clearly revealed that all tested inducers significantly reduced disease severity compared to the control treatments in both tested strawberry cultivars, however, Boric acid was generally the most effective in suppressing disease severity compared to the other used inducers. The element boron is a crucial micronutrient for plants for it is involved in fundamental process related to plant growth. The deficiency of boron leads to the deformation of plant growth since it majorly affects the cell wall formation and elongation of plant cells as well as its interfering with the function of different proteins and enzymes (Shireen et al., 2018). To avoid or compensate boron deficiency plants are being fertilized with boron, usually in the form of Boric acid (Rolshausen and Gubler, 2005; Shireen et al., 2018). From the plant disease perspective, several investigations proved that Boric acid can be used in plant disease control since it can directly affect the growth of several pathogens and suppresses their growth as mentioned above (Rolshausen and Gubler, 2005 and Smilanick and Sorenson, 2001). In a study carried out by Frenkela et al. (2010) they found that foliar treatment of tomato with boron significantly suppressed the infection with Phytophthora infestans the casual pathogen of late blight. They revealed that boron may have a weak direct fungicidal effect on the pathogen, but it has stimulated a systemic resistance effect in tomato and resulted in decreasing the disease severity compared to control. Some reports stated that the mechanism by which boron induces the systemic resistance in plants is by affecting phenolic compounds and by increasing the activity of polyphenoloxidase (PPO) enzyme (Camacho-Cristóbal et al., 2008 and Frenkela et al., 2010). Data from our investigation suggest that the mechanism by which Boric acid suppressed gray mold severity is related to the inducing of resistance activity as strawberry plants were treated during field growth period but the impact on suppressing the infection of fruits during post-harvest stage was obviously significant. However, the direct antifungal effect of Boric acid on B. cinerea can't be ruled out unless we consider the used concentration of Boric acid.

The potential of Ascorbic acid as an antioxidant in plant disease resistance is well known, it plays a significant role in the scavenging activity against reactive oxygen species. Hence, its role in rescuing plants from detrimental effects of continuous stresses they are liable to is proved. Therefore, in terms of induced resistance in plants, Ascorbic acid is widely involved in regulating the defense pathways induced by the application of chemical inducers or due to any type of stress (Boubakri, 2017). Moreover, it was also used as an inducer for resistance when exogenously applied on different plants (Boubakri, 2017). Applying Ascorbic acid in the management of rice blast disease was 
found to induce resistance against the pathogen and suppress the disease severity in addition to directly affect the growth of Magnaporthe oryzae the causal pathogen (Egan et al., 2007).

Our results also demonstrated that Oxalic acid is very effective in suppressing gray mold severity on strawberry fruits especially in the higher concentration that have been used. Many reports suggest that Oxalic acid is involved in the production of hydrogen peroxide $\mathrm{H}_{2} \mathrm{O}_{2}$ and therefore can directly inhibit the growth of the pathogens and suppress the infection of plants by these pathogens (Kátay et al., 2011; Khan et al., 2011; Zheng et al., 2007). Investigations supporting the role of Oxalic acid in inducing resistance in plants were also reported and this effect was predominantly related to the activity of different oxidative enzymes like PPO and POX (Shafique et al., 2011).

In this investigation, we attempted to elucidate the association between the induction of resistance in strawberry plants and the possible mechanisms involving different metabolic activities. The activity of some oxidative enzymes involved in the plant defense response was studied.

We found a positive correlation between the reductions in disease severity and the increase in peroxidase (POX) and polyphenoloxidase (PPO) activities as a significant increase in the activities were reported with different treatments. However, for catalase (CAT), in most treatments the activity was inhibited compared to the control either in artificially inoculate or naturally infected fruits, but Boric acid and Ascorbic acid treatments enhanced the activity of the enzyme in case of cultivar Sensation affected by natural infection. In general, some discrepancies in the results were noticed and therefore a consistent conclusion could not be drawn. The effect of Boric acid treatments on the activity of PPO and POX were obvious in this study. The premise of the effect of Boric acid in increasing the phenolic compounds concentrations and peroxidases activity was explained earlier (Frenkelaet al., 2010).

Ample research demonstrated the link between the activity of various kinds of oxidative enzymes and induced defense responses in plants treated by elicitors or affected by biotic or abiotic stresses (Baysal et al., 2003; Lin et al., 2011 and Sarhan, 2018) found that treating tomato seedlings with ASM (Acibenzolar-S-methyl) induced defense against bacterial canker caused by Clavibater michiganensis ssp. michiganensis this was correlated with significant increase in POX activity.

Anand et al. (2007) reported that the activity of POX, PPO and catalase were enhanced in tomato plants treated with the chemical inducer azoxystrobin and those plants showed resistance to A. solani and Septoria lycopersici. Also, they found that the activity of catalase enzyme was increased immediately after challenging the plants with both pathogens, but a remarkable decrease was then detected.

Oxidative enzymes are involved in fundamental processes in plant cells and play different roles during plant growth. PPO and $\mathrm{POX}$ are involved in the lignification process in plant cell wall formation, therefore, they play a significant role in the enforcing of the plant cell and hindering the pathogens from further invasion (Kombrink and Somssich, 1995; Lin et al., 2011 and Sarhan et al., 2018).

In this study the effect of treating plants with different elicitors in inducing the production of phenolic compounds in addition to the reactive oxygen species (ROS) scavenging activity in strawberry fruits were studied. The DPPH method was used to assess the potent activity of the antioxidants as a result of using chemical elicitors. The correlation between the total phenolic compounds content in fruits and the antioxidant scavenging activity was remarkable.

Reactive oxygen species (ROS) are constantly produced as byproducts during cell division and normal metabolic processes in plants, although they are known with their harmful oxidative effects such as deteriorating proteins and enzymes in plant cells. Therefore, plants are normally capable of regulating ROS production and neutralizing the negative effects of reactive oxygen species (ROS) produced during normal conditions of plant growth process by producing various types of antioxidants either enzymatic or non-enzymatic. However, when plants are invaded by pathogens or being subjected to any kind of stress, ROS are over produced and the scavenging activity has to be more effective to mitigate the detrimental effects of ROS (Apel and Hirt, 2004; Molyneux, 2004 and Choudhury et al., 2013).

It is well known that phenolic compounds are one of the major secondary metabolites produced in plant cells, and most of the antioxidants produced in plant cells are phenols (Romanazzi et al., 2016). However, the assessment of scavenging activity in fruits doesn't solely rely on the phenolic compounds since various types of 
enzymes, such as peroxidases and catalases, are being involved as mentioned earlier.

\section{CONCLUSIONS}

The three acids used in this investigation proved to have a remarkable effect as inducers of defense in strawberry plants and indeed provided the fruits with some resistance against gray mold during post-harvest stage. However, Boric acid was the most potent in inducing the SAR effect. It was also noted that there was a correlation between the concentration and the efficacy of the used inducer. Generally, the higher concentration of tested acids ( $40 \mathrm{mM}$ ) was more effective in reducing the severity of gray mold compared to the lower concentration $(20 \mathrm{mM})$. Our results also suggest that strawberry cultivars may respond differently to the used inducer or eliciting element. Although the cultivar could be more susceptible, it may be more responsive to the inducer in SAR response. The cultivar Fortuna seemed to be more resistant; however, the Sensation cultivar was more reactive to the inducing efficacy of the elicitors. Which was obvious from the total phenolic content.

\section{COMPETING INTERESTS}

The authors declare that they have no competing interests.

\section{ACKNOWLEDGMENTS}

The authors are grateful to Prof. Dr. Said Omar, Plant Pathology Research Institute, Agricultural Research Center, 12619, Giza, Egypt, for reviewing the manuscript.

\section{REFERENCE}

Allam, A.I. and Hollis, J.P.; 1972. Sulfide inhibition of oxidases in rice roots. Phytopathology, 62: 634-639.

Anand, T.; Chandrasekaran, A.; Kuttalam, S.; Raguchander, T.; Prakasam, V. and Samiyappan, R. 2007. Association of some plant defense enzyme activities with systemic resistance to early leaf blight and leaf spot induced in tomato plants by azoxystrobin and Pseudomonas fluorescens. Journal of Plant Interactions, 2: 233-244.

Apel, K. and Hirt, H., 2004. Reactive oxygen species: metabolism, oxidative stress, and signal transduction. Annual Review of Plant Biology 55: 373-399.
Arora, R.K. 2013. Comparative efficacy of Boric acid and pencycuron for management of black scurf of potato. Potato Journal 40, 60-64.

Awadalla, O., A, 2008. Induction of systemic acquired resistance in tomato plants against early blight disease. The Egyptian Journal of Experimental Biology (Botany) 4, $53-59$.

Barros, L.; Baptista, P. and Ferreira, I.C. 2007. Effect of Lactarius piperatus fruiting body maturity stage on antioxidant activity measured by several biochemical assays. Food and Chem. Toxicol. 45: 1731-1737.

Baysal, Ö.; Soylu, E.M. and Soylu, S. 2003. Induction of defence-related enzymes and resistance by the plant activator acibenzolarS-methyl in tomato seedlings against bacterial canker caused by Clavibacter michiganensis ssp. michiganensis. Plant Pathology, 52: 747753.

Botanga, C.J.; Bethke, G.; Chen, Z.; Gallie, D.R.; Fiehn, O. and Glazebrook, J. 2012. Metabolite profiling of Arabidopsis inoculated with Alternaria brassicicola reveals that ascorbate reduces disease severity. Molecular PlantMicrobe Interactions, 25: 1628-1638.

Boubakri, H. 2017. The role of ascorbicacid in plant-pathogen interactions, In: Hossain, M.A.; Munné-Bosch, S.; Burritt, D.J.; DiazVivancos, P.; Fujita, M. and Lorence, A. (Eds.), Ascorbic Acid in Plant Growth, Development and Stress Tolerance. Springer International Publishing, Cham, pp. 255-271.

Camacho-Cristóbal, J.J.; Rexach, J. and González-Fontes, A. 2008. Boron in plants: deficiency and toxicity. Journal of Integrative Plant Biology 50: 1247-1255.

Choquer, M.; Fournier, E.; Kunz, C.; Levis, C.; Pradier, J.M.; Simon, A. and Viaud, M. 2007. Botrytis cinerea virulence factors: new insights into a necrotrophic and polyphageous pathogen. FEMS microbiology letters, 277: 110.

Choudhury, S.; Panda, P.; Sahoo, L. and Panda, S.K. 2013. Reactive oxygen species signaling in plants under abiotic stress. Plant Signaling \&Behavior 8: e23681.

Duncan, D.B. 1955. Multiple Range and Multiple F Tests. Biometrics, 11: 1-42.

Durrant, W.E. and Dong, X. 2004. Systemic acquired resistance. Annual review of phytopathology, 42: 185-209.

Egan, M.J.; Wang, Z.Y.; Jones, M.A.; Smirnoff, N. and Talbot, N.J. 2007. Generation of reactive oxygen species by fungal NADPH oxidases is required for rice blast disease. 
Proc. Natl. Acad. Sci. USA 104: $11772-$ 11777.

Elad, Y.; Williamson, B. and Tudzynski, P.D.N. 2007. Botrytis: biology, pathology and control. Springer, Dordrecht, The Netherlands. 428pp.

FAOSTAT, 2018. FAOSTAT Database. Rome, Italy: FAO. http://www.fao.org

Feliziani, E.; Landi, L. and Romanazzi, G. 2015. Preharvest treatments with chitosan and other alternatives to conventional fungicides to control postharvest decay of strawberry. Carbohydrate Polymers, 132: 111-117.

Frenkela, O.; Yermiyahub, U.; Forbes, G.A.; Fryd, W.E. and Shtienberg, D. 2010. Restriction of potato and tomato late blight development by sub-phytotoxic concentrations of boron.Plant Pathology, 59: 626-633.

Fu, Z.Q. and Dong, X., 2013. Systemic acquired resistance: turning local infection into global defense. Annual Review of Plant Biology, 64: 839-863.

Gao, Q.M.; Kachroo, A. and Kachroo, P. 2014. Chemical inducers of systemic immunity in plants.Journal of experimental botany, 65: 1849-1855.

Gomez, K.A. and Gomez, A.A. 1984. Statistical procedures for agricultural research, $2^{\text {nd }} e d$. John Wiley and Sons, New York, USA. 680pp.

Hahn, M. 2014. The rising threat of fungicide resistance in plant pathogenic fungi: Botrytis as a case study. J. Chem. Biol., 7: 133-141.

Hammerschmidt, R.; Nuckles, E.M. and Kuć, J. 1982. Association of enhanced peroxidase activity with induced systemic resistance of cucumber to Colletotrichum lagenarium. Physiological Plant Pathology, 20: 73-82.

Ikegaya, A.; Ohba, S.; Nakajima, T.; Toyoizumi, T.; Ito, S. and Arai, E. 2020. Practical longterm storage of strawberries in refrigerated containers at ice temperature. Food Sci. Nutra., 8:5138-5148.

Jayaraj, J.; Bhuvaneswari, R.; Rabindran, R.; Muthukrishnan, S. and Velazhahan, R. 2010. Oxalic acid-induced resistance to Rhizoctonia solani in rice is associated with induction of phenolics, peroxidase and pathogenesisrelated proteins. Journal of Plant Interactions, 5: 147-157.

Kátay, G.; Tyihák, E. and Kátay, E. 2011. Effect of ascorbigen and 1'-methylascorbigen on disease resistance of bean plants to Uromyces phaseoli. Natural product communications, 6 : 611-615.
Kato, M. and Shimizu, S. 1987. Chlorophyll metabolism in higher plants. VII. Chlorophyll degradation in senescing tobacco leaves; phenolic-dependent peroxidative degradation. Canadian Journal of Botany, 65: 729-735.

Khalil, M.E. and Ashmawy, E.M.A. 2019. Induction of systemic disease resistance in cucumber plants treated by the spray of some biotic and abiotic agents to control downy mildew disease. Egypt. J. Agric. Res., 97(1): 19-37.

Khan, T.A.; Mazid, M. and Mohammad, F. 2011. Role of Ascorbic acid against pathogenesis in plants. Journal of Stress Physiology \& Biochemistry, 7: 222-234.

Kombrink, E. and Somssich, I.E. 1995. Defense responses of plants to pathogens., In: Andrews, J.H., Tommerup, I.C. (Eds.), Advances in Botanical Research (incorporating Advances in Plant Pathology). Academic Press, London; New York, pp.1-34.

Lawton, K.A.; Friedrich, L.; Hunt, M.; Weymann, K.; Delaney, T.; Kessmann, H.; Staub, T. and Ryals, J. 1996. Benzothiadiazole induces disease resistance in Arabidopsis by activation of the systemic acquired resistance signal transduction pathway. The Plant Journal for Cell and Molecular Biology, 10: 71-82.

Li, J.; Trivedi, P. and Wang, N. 2016. Field evaluation of plant defense inducers for the control of Citrus Huanglongbing. Phytopathology, 106: 37-46.

Lin, J.; Gong, D.; Zhu, S.; Zhang, L. and Zhang, L. 2011. Expression of PPO and POD genes and contents of polyphenolic compounds in harvested mango fruits in relation to Benzothiadiazole-induced defense against anthracnose. Scientia Horticulture, 130: 8589.

Mayer, A.M.; Harel, E. and Ben-Shaul, R. 1966. Assay of catechol oxidase - a critical comparison of methods. Phytochemistry 5: 783-789.

Meir, S.; Droby, S.; Davidson, H.; Alsevia, S.; Cohen, L.; Horev, B. and Philosoph-Hadas, S. 1998. Suppression of Botrytis rot in cut rose flowers by postharvest application of methyl jasmonate. Postharvest Biology and Technology, 13: 235-243.

Métraux, J.P.; Signer, H.; Ryals, J.; Ward, E.; Wyss-Benz, M.; Gaudin, J.; Raschdorf, K.; Schmid, E.; Blum, W. and Inverardi, B. 1990. Increase in salicylic Acid at the onset of systemic acquired resistance in cucumber. Science (New York, N.Y.) 250, 1004-1006. 
Mohamed, F.G.; Abdel-Mageed, M.H.; Hafez, M.S.; Soltan, H. H.; Rahsid, I. A. and AbdelRahman, F.A. 2015. Effect of some organic acids on anatomical, physiological changes and post-harvest diseases of snap bean pods', J. Biol. Chem. Environ. Sci., 10(3): 287-311.

Mohammadi, A.; Hashemi, M. and Hosseini, S.M. 2015. The control of Botrytis fruit rot in strawberry using combined treatments of Chitosan with Zataria multiflora or Cinnamomum zeylanicum essential oil. Journal of Food Science and Technology, 52: 7441-7448.

Molyneux, P., 2004. The use of the stable free radical diphenylpicrylhydrazyl (dpph) for estimating antioxidant activity. Songklanakarin J. Sci. Technol., 26: 211-219.

Petrasch, S.; Knapp, S.J.; van Kan, J.A.L. and Blanco-Ulate, B. 2019. Grey mold of strawberry, a devastating disease caused by the ubiquitous necrotrophic fungal pathogen Botrytis cinerea. Molecular Plant Pathology, 20: 877-892.

Qin, G.; Zong, Y.; Chen, Q.; Hua, D. and Tian, S. 2010.Inhibitory effect of boron against Botrytis cinerea on table grapes and its possible mechanisms of action. International Journal of Food Microbiology, 138, 145-150.

Rolshausen, P.E. and Gubler, W.D. 2005. Use of Boron for the Control of Eutypa dieback of grapevines. Plant Disease, 89: 734-738.

Romanazzi, G.; Sanzani, S.M.; Bi, Y.; Tian, S.; Gutiérrez Martínez, P. and Alkan, N. 2016. Induced resistance to control postharvest decay of fruit and vegetables. Postharvest Biology and Technology 122, 82-94.

Romanazzi, G.; Nigro, F. and Ippolito, A.E. 2000. Effectiveness of pre and postharvest chitosan treatments on storage decay of strawberries. Frutticoltura, 62: 71-75.

Sarhan, E.A.D. 2018. Induction of induced systemic resistance in fodder beet (Beta vulgaris L.) to Cercospora leaf spot caused by (Cercospora beticola Sacc.). Egypt J. Phytopathol., 46(2): 39-59.

Sarhan E.A.D.; El-Far, E.M.M. and Ebrahiem, A.M.Y. 2018. Systemic resistance in snap bean (Phaseolus vulgaris L.) elicited by some chemicals and biotic inducers against white mold disease caused by (Sclerotinia sclerotiorum). Egypt J. Phytopathol., 46(2): 61-84.

Shafique, S.; Anjum, T.; Shafique, S.; Ahmad, A.; Akram, W. and Bashir, Z. 2011. Induction of systemic defenses in plants under the activity of dynamic inducers. Mycopath., 9(2): 95-104.

Shi, X.; Li, B.; Qin, G. and Tian, S. 2012. Mechanism of antifungal action of borate against Colletotrichum gloeosporioides related to mitochondrial degradation in spores. Postharvest Biology and Technology, 67: 138-143.

Shireen, F.; Nawaz, M.A.; Chen, C.; Zhang, Q.; Zheng, Z.; Sohail, H.; Sun, J.; Cao, H.; Huang, Y. and Bie, Z. 2018. Boron: Functions and approaches to enhance its availability in plants for sustainable agriculture. International journal of molecular sciences, 19 (1856).

Silva, J.M.da.; Medeiros, M.d.B.C.L.; Oliveira, J.T.C.; Medeiros, E.V.d.; Souza-Motta, C.M.d. and Moreira, K.A. 2018. Resistance inducers and biochemical mechanisms in the control of anthracnose in cowpea. Ciencia e investigación agrarian, 45: 290-300.

Siripornvisal, S.; Rungprom, W. and Sawatdikarn, S. 2009. Antifungal activity of essential oils derived from some medicinal plants against grey mould (Botrytis cinerea). Asian Journal of Food and Agro-Industry, Special Issue S229-S233.

Smilanick, J.L. and Sorenson, D. 2001. Control of postharvest decay of citrus fruit with calcium polysulfide. Postharvest Biology and Technology 21, 157-168.

Terry, L.A. and Joyce, D.C. 2004. Elicitors of induced disease resistance in postharvest horticultural crops: a brief review. Postharvest Biology and Technology 32, 1-13.

Tulipani, S.; Mezzetti, B.; Capocasa, F.; Bompadre, S.; Beekwilder, J.; de Vos, C.H.; Capanoglu, E.; Bovy, A. and Battino, M. 2008. Antioxidants, phenolic compounds, and nutritional quality of different strawberry genotypes. Journal of Agricultural and Food Chemistry, 56: 696-704.

Walters, D.R.; Ratsep, J. and Havis, N.D. 2013. Controlling crop diseases using induced resistance: challenges for the future. Journal of Experimental Botany, 64: 1263-1280.

Zheng, X.; Tian, S.; Gidley, M.J.; Yue, H. and Li, B. 2007. Effects of exogenous Oxalic acid on ripening and decay incidence in mango fruit during storage at room temperature. Postharvest Biology and Technology, 45: 281-284.

Zhou, M. and Wang, W. 2018. Recent Advances in Synthetic Chemical Inducers of Plant Immunity. Front. Plant Sci., 9:1613. 